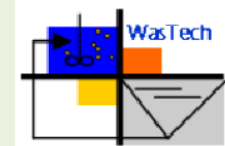

\title{
Management of Peat Fires on Smoldering Phase (Case Study: District Siak and District Kampar Riau Province)
}

\author{
Syafrudin, Haryono S. Huboyo, Bella Nasila D.**) \\ $\left({ }^{* *}\right.$ Environmental Engineering Program, Faculty of Engineering, University of Diponegoro \\ Prof.H. Sudarto SH Street Tembalang, Semarang, Indonesia, 50275 \\ email: udin_syaf@yahoo.com
}

\begin{abstract}
Oil palm plantation has been growing rapidly to fulfill resource stock for oil palm industry in Indonesia since 1967. Total area for oil palm plantations had increased from 5.6 million ha in 2005 to about 7.8 million ha in 2009. However for preparing the land for cultivation, improper land clearing by drainage peatland and prescribed burning induce main cause of uncontrolled peatland fires. Peatland fires usually occur at smoldering phase due to subsurface burning. During this smoldering phase, we measure near fire PM2.5 and its inorganic ions characteristics at Riau Province. Also based on observation in the field we proposed a buffer zone at burning site to prevent burning expansion. PM2.5 measurements were collected by Denuder at constant flow rate 10 $L /$ min, while IC were used to quantify its inorganic ions. PM 2.5 concentrations ratio relative to the background samples were quite high i.e at more than forty times reaching ambient concentration more than $2000 \mu \mathrm{g} / \mathrm{m}^{3}$. However the deviation of measured PM2.5 is quite high $(531 \mu \mathrm{g} / \mathrm{m} 3)$ indicating high variability of occurring fires between sites. The inorganic ions composition were dominated by ions $\mathrm{Cl}^{-}, \mathrm{SO}_{4}^{2-}, \mathrm{NH}_{4}^{+}, \mathrm{K}^{+}$. Slightly different composition with other land burning might be caused by pesticide residue within the oil palm plantation. Using observed peatland fire at the site, we design a proposed buffer zone to abate ambient PM 2.5 which has an area of 4.4 ha. This buffer zone size might different with other burning condition at different sites.

Keywords: biomass burning, buffer zone, inorganic ions, particles, peat land
\end{abstract}

Submission: September 20, $2015 \quad$ Correction: October 11, $2015 \quad$ Accepted: October 15, 2015

Doi: http://dx.doi.org/10.12777/wastech.3.2.47-52

[How to cite this article: Syafrudin, S., Huboyo, H.S., Nasila, B.D. (2015). Management of Peat Fires on Smoldering Phase (Case Study: District Siak and District Kampar Riau Province). Waste Technology, 3(2),47-52. doi: http://dx.doi.org/10.12777/wastech.3.2.47-52

\section{INTRODUCTION}

Most of the biomass burning are occuring in many tropical places such as in Southeast Asia's tropical forests and savannas of Africa or South America. The majority of biomass burning (90\%) caused by human activity, while natural fires as a result of sun exposure account for only $10 \%$. Areas that often experience of biomass burning varies among tropical savanna, tropical forests, boreal forests, peat and the remnants of agriculture (Levine, 2000).

In Indonesia, peatland burning is likely as annual event. Long drought during dry season, improper land clearing by drainage peatland and prescribed burning are the main cause of uncontrolled peatland fires. Usually on expansion of agricultural area, the people use the peatland by burning the peat. Indeed, Riau Province in Indonesia is one of the major hotspots for peat fires during the dry season (Fujii et al., 2014).

Peat fires are characterized by a significant amount of smoke and emissions due to slow long burning. In the case of peat, because the chemical properties of peat and a high moisture content, the smoldering combustion process usually takes place characterized by a low combustion efficiency. Hamada et al, 2013 showed smoldering combustion in peat land fire using calculated values of $\mathrm{ER}_{\mathrm{CO}} / \mathrm{CO2}$. In the smoldering fire process, the emissions are wide varieties of compounds are released that are not oxidized completely (eg CO, VOCs, PAHs). These compounds, surely, are more dangerous than the emissions released during flaming combustion i.e combustion at high temperatures (Muraleedharan et al., 2000). Smoldering fire emits particulates more than flaming fires. In several studies, it was found that many aerosol formation occurs at this smoldering stage, including many particulates formed by the condensation of volatile organic materials in various surface particles (Reid et al., 2005).

Particulate Matter $\left(\mathrm{PM}_{2.5}\right)$ is one of the main emissions from peat fires. Concentration of Particulate Matter $\left(\mathrm{PM}_{2.5}\right)$ as a result of peat fires in Siak in 2012 
was $7120 \pm 3620 \mathrm{~g} / \mathrm{m}^{3}$. This value is more than 300 times compare to no peat fires event, ie $23.9 \pm 2: 53$ $\mathrm{g} / \mathrm{m}^{3}$. The content of organic carbon (OC) of $\mathrm{PM}_{2.5}$ is $71.0 \% \pm 5.11$ and content of the element carbon (EC) was $39.1 \pm 5.08 \%$ (Fujii et al., 2014).

The impact of $\mathrm{PM}_{2.5}$ on human health could be short-term (daily or weekly) and long term (monthly or yearly). Short-term impact of $\mathrm{PM}_{2.5}$ exposure is a mild respiratory problems such as co gh and asthma symptoms. Long-term impact of exposure to $\mathrm{PM}_{2.5}$ is lung cancer and cardiopulmonary disorders. Long-term exposure to PM 2.5 was associated with an increased long-term risk of cardiopulmonary mortality by $6-13 \%$ per $10 \mathrm{~g} / \mathrm{m}^{3} \mathrm{PM}_{2.5}$ (WHO, 2013).

In this study, $\mathrm{PM}_{2.5}$ and its inorganic ions emitted from peatland fires (during smoldering phase) are identified at hotspots of peat fire in Riau province. We also propose a method for reducing the ambient $\mathrm{PM}_{2.5}$ concentration due to peatland fire by developing a buffer zone at the fire site. Thus the purpose of the study is:

1. Analyzing ionic species of near fire $\mathrm{PM}_{2.5}$ characteristic resulted from peat fires

2. Provide recommendations for environmental improvement based on the current research results.by proposing buffer zone to prevent expanding fires.

\section{METHODS AND EQUIPMENT}

\section{Sampling site}

Complete description of the sampling site is depicted in Figure.1 The first sampling sites was located in the village Langkai, Siak. The sampling sites were within the oil palm plantations where the land burned about 6 ha. In this site, we measured at four points i.e namely fire point $1\left(0^{\circ} 53^{\prime} 31,31\right.$ "N $\left.102^{\circ} 1^{\prime} 57,00^{\prime \prime} \mathrm{T}\right)$; fire point $2\left(0^{\circ} 53^{\prime} 30,00{ }^{\prime} \mathrm{N} 102^{\circ} 1^{\prime} 56,48^{\prime \prime} \mathrm{T}\right)$; fire point 3 $\left(0^{\circ} 53^{\prime} 33,75\right.$ "N $\left.102^{\circ} 1^{\prime} 58,85^{\prime \prime} \mathrm{T}\right)$; and fire point 4 (053'35,23 "N $\left.102^{\circ} 2^{\prime} 0,80 " \mathrm{~T}\right)$.

The second sampling site was located in the village of Long Rimbo, Kampar. This is unused land consists of shrub/ bush, fallen trees, and peat soil about 3 ha. The sampling point were fire point $5 \quad\left(0^{\circ} 25^{\prime} 31.87 \mathrm{~N}\right.$ $101^{\circ} 18^{\prime} 4.85$ "T); fire point $6\left(0^{\circ} 25^{\prime} 28,26^{\prime \prime} \mathrm{N} 101^{\circ} 18^{\prime} 5,96\right.$ "T); and fire point $7\left(0^{\circ} 25^{\prime} 26,77^{\prime \prime} \mathrm{N} 101^{\circ} 18^{\prime} 3,34\right.$ "T $)$. The third sampling site as background site was at village Kampung Dalam, Siak, $\left(0^{\circ} 48^{\prime} 14.10^{\prime \prime} \mathrm{N} 102^{\circ} 3^{\prime} 12.24 " \mathrm{E}\right)$. These locations is far remote from the burning site e.g more than $10 \mathrm{~km}$ which is free from smoke fire.

\section{Measurement and Analytical Method}

\section{PM $_{2.5}$ measurement}

Near fire $\mathrm{PM}_{2.5}$ measurements were collected by means of Denuder (3500 models ChemComb denuder Thermo, Thermo) equipped with Pump (Leland Legacy). This denuder inlet was set at height $\pm 1.5 \mathrm{~m}$ above ground with the pump was put at ground with constant flow $10 \mathrm{~L} / \mathrm{min}$. Pump pre-calibration was done by bubble soap calibrator (Gilian Gilibrator). In order to minimize interference for chemical analysis, we used teflon filters (SKC). About 4 hours, we collected the sample for each measurement. While for background measurements we collected for 12 hours. Sampling at Siak district were performed at dates 2, 3, 4, 5, 11 and 12 of July 2015. While at Kampar district the measurement were taken at less days i.e at dates 7,8 , and 9 of July 2015.

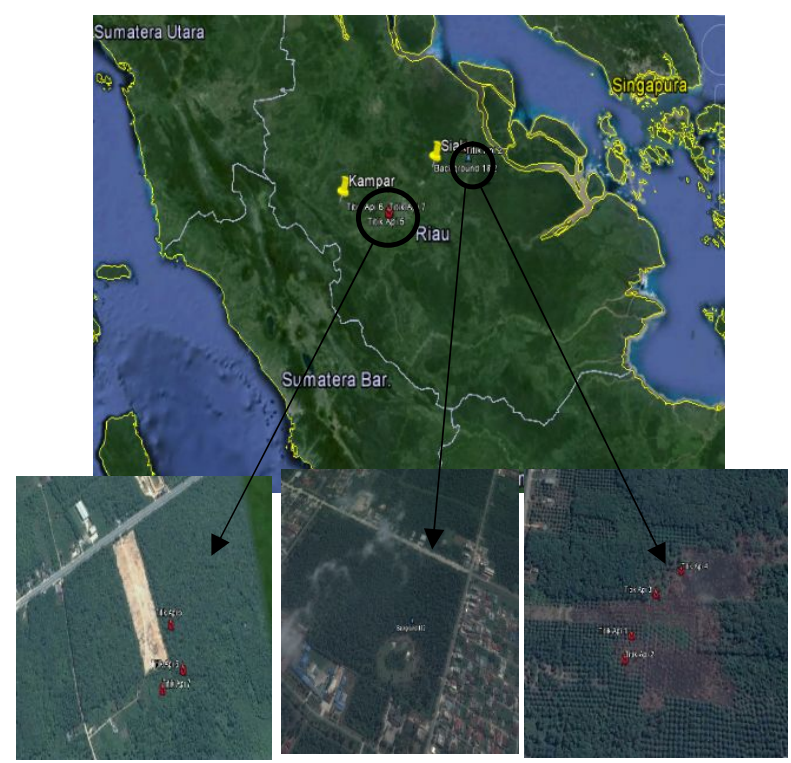

Figure 1. Research Sampling Site

We used supporting meteorological data (ambient temperature and barometric pressure) by inspecting pump data, while for wind data (for estimating wind rose) and relative humidity were adopted from www.accuweather.com.

\section{Analytical Method}

$\mathrm{PM}_{2.5}$ concentration were quantified by gravimetric method by weighing the filters (pre- and after sampling) using \pm 1 g accuracy microbalance (Sartorius, ME5-F) in a conditioned room (30 - 40\%). In addition, water soluble inorganic ions $\left(\mathrm{Cl}^{-}, \mathrm{NO}^{3-}, \mathrm{SO}_{4}{ }^{2-}, \mathrm{Na}^{+}, \mathrm{NH}_{4}^{+}, \mathrm{K}^{+}\right.$, $\mathrm{Mg}^{2+}$, and $\mathrm{Ca}^{2+}$ ) were analyzed using ion chromatography (HIC-10A, Shimadzu Co). This analytical method was performed at Chemical Laboratory, Department of Socio-Environmental Energy Sciences, Graduate School of Energy Science Kyoto University, Japan. Ionic balances (both cations and anions) were summarized. We finally summed up both cations and anions for each filter and formed the percentage summary of the $\mathrm{PM}_{2.5}$ mass concentration. For comparison of ionic composition, background sample (non fire) was also provided. 


\section{Calculation of Concentration}

The procedure for calculating the average mass particle concentration during the sampling period is based on ChemComb Operating Manual 2006 and is dictated as follows:

$M C=\left(D W \times 10^{6}\right) / V$

where:

$\mathrm{MC}=$ mass concentration $\left(\mathrm{g} / \mathrm{m}^{3}\right)$

$\mathrm{DW}=$ mass difference before pre-sampling and post- sampling after corrected by blank filters

$10^{6}=$ conversion factor of gram $(\mathrm{g})$ to micrograms ( g)

$\mathrm{V}=$ volume of air passing thro gh the filter

\section{Calculation of Emissions from Land Burned}

Emissions from the burning of land is calculated based on the equation established by the US EPA (1995):

$\mathrm{Ei}=\mathrm{Pi} \times \mathrm{L} \times \mathrm{A}$

where:

$\mathrm{Ei} \quad=$ total emissions of pollutant (mass of pollutant)

$\mathrm{Pi}=$ ratio of emissions (pollutants mass/burning material)

L = combustion efficiency (fuel burning mass / area burning)

A $=$ area of land on fire

\section{Calculation of Dispersion Pollutants}

Dispersion concentration of pollutants at a certain distance in the direction of the wind is calculated using Equation Gauss, there is:

$$
\mathrm{C}=\mathrm{Q} \cdot \mathrm{K} / \pi\left(\sigma_{\mathrm{y}} \cdot \sigma_{\mathrm{z}} \cdot \mathrm{U}_{\mathrm{z}}\right) \exp \left(-1 / 2\left(\mathrm{H} / \sigma_{\mathrm{z}}\right)\right.
$$

Description :

$\mathrm{C}=$ concentration of pollutants at a certain distance in the direction of the wind $\left(\mathrm{g} / \mathrm{m}^{3}\right)$

$\mathrm{K}=1 \times 10^{6}$ (coefficient scale for $\mathrm{Q}$ in $\mathrm{g} / \mathrm{s}$ and $\mathrm{C}$ in $\mathrm{g}$ $/ \mathrm{m}^{3}$ )

$\sigma_{\mathrm{y}}, \sigma_{\mathrm{z}}=$ standard deviation of the distribution of concentration (C) in the direction of $\mathrm{x}$ and $\mathrm{y}$ (meters)

$\mathrm{u} \quad=$ wind speed $(\mathrm{m} / \mathrm{s})$

$\mathrm{H} \quad=$ height of the source $(\mathrm{m})$

$\mathrm{x}=$ distance of the source to receptor (meters)

$\mathrm{U}_{\mathrm{z}} \quad$ = wind speed at height $\mathrm{z}$

\section{Calculation of Total Tree}

The final concentration $\left(\mathrm{g} / \mathrm{m}^{3}\right)\left(\mathrm{C}_{\mathrm{t}}\right)$

$\mathrm{C}_{\mathrm{t}}=\frac{V \times C \times \text { absorption area }}{\text { planting area } \times \text { tree } \text { [eig[ } \mathrm{W} t}$

Description (Nowarket al., 1994; Fuller et al., 2009): $\mathrm{C}_{\mathrm{t}}=$ Final concentration $\left(\mathrm{g} / \mathrm{m}^{3}\right)$
$\mathrm{V}_{\mathrm{d}} \quad=$ desposition velocity, vegetation absorption velocity $(\mathrm{m} / \mathrm{s})$

$\mathrm{C}=$ concentration, pollutant concentrations ( $\mathrm{g}$ $\left./ \mathrm{m}^{3}\right)$

Absorption area per tree $=\left(\mathrm{m}^{2}\right)$

Planting area $=\left(\mathrm{m}^{2}\right)$

Tree height $=(\mathrm{m})$

The number of trees needed

$=\frac{\text { Concentration }}{\text { Final Concentration }(C t)}$

The required area for planting trees: Number of trees $\mathrm{x}$ the area for planting $\mathrm{x}$ wind direction.

\section{RESULTS AND DISCUSSION}

\section{$\mathbf{P M}_{2.5}$ Concentration}

We successfully collected 13 fire samples, 2 non-fire samples and 2 fields blank. Measurement period in Siak district was longer than in Kampar district due to larger and more intensified burning in Siak area rather than in Kampar area. The results of $\mathrm{PM}_{2.5}$ concentrations are listed in Table 1.

Table 1. $\mathrm{PM}_{2.5}$ Concentration

\begin{tabular}{llr}
\hline Location & \multicolumn{1}{c}{ Sample } & $\mathbf{P M}_{2.5}\left(\mu \mathrm{g} / \mathbf{m}^{3}\right)$ \\
\hline & Fire1 & 665.90 \\
\cline { 2 - 3 } & Fire2 & 519.48 \\
\cline { 2 - 3 } Siak District & Fire5 & 988.01 \\
\cline { 2 - 3 } & Fire7 & 1370.70 \\
\cline { 2 - 3 } & Fire8 & 2163.49 \\
\cline { 2 - 3 } & Non-Fire1 & 54.02 \\
\cline { 2 - 3 } & Non-Fire2 & 87.32 \\
\hline \multirow{3}{*}{ Kampar } & Fire9 & 1165.99 \\
\cline { 2 - 3 } District & Fire10 & 695.98 \\
\cline { 2 - 3 } & Fire11 & 452.89 \\
\cline { 2 - 3 } & Fire12 & 947.90 \\
\hline
\end{tabular}

The observed fire generally in the smoldering phase which is characterized by slow burning, high emission of smoke and long burning period. In this smoldering fire, sub surface fire occurred making difficult to extinguish the fire. In this smoldering fire, the temperature at the surface could reach $276.85^{\circ} \mathrm{C}$ (Usup et al., 2014). The deviation of measured $\mathrm{PM}_{2.5}$ is quite high $\left(531 \mathrm{~g} / \mathrm{m}^{3}\right)$ indicating high variability of occuring fires between sites. Rastogi et al, 2014 also shows variability of peatland fires during day time and night time.

$\mathrm{PM}_{2.5}$ concentrations ratio relative to the background samples were quite high i.e at more than forty times. In this case, peat fires deteriorated ambient air quality and potentially threat serious health problems to the inhabitants.

Based on the report from Forest Fire Preparedness Center (BPBD) of Riau Province, as of September 28 $8^{\text {th }}$ 
2015 , the number of patients with respiratory disease records as many as 38.898 people consists of asthma patient as many as 1,801 people, 2,411 suffered from eye irritation, and 3,156 people suffered from skin disorders.

\section{Inorganic ion Composition to $\mathbf{P M}_{2.5}$ Concentration}

Certain cationic species i.e $\mathrm{Mg}^{2+}$ and $\mathrm{Ca}^{2+}$ were below detection limits. Thus we only got three anionic and three cationic species for further analysis.

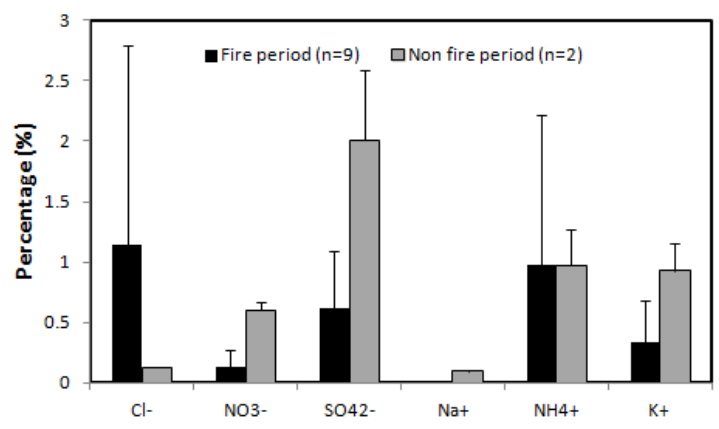

Figure 2. Ratio of Ionic Species to PM2.5

There are so much uncertainties on ionic species concentration during burning fires indicated by high standard deviation. However, low standard deviation is showed for background samples.

Higher $\mathrm{Cl}$ ratio in fires samples indicate much contributor of biomass burning rather than from seasalt aerosol since the site is far remote from the sea. This also stated by Chow et al, 2004 that biomass burning emission is characterized by high proportion of $\mathrm{Cl}$ ionic species. Higher sulfates in the samples may be caused by higher content of peat land by accumulated pesticide residu. Ammonium and potassium also showed higher concentration indicate although in smoldering phase the peat fires still emit high content of these species. However, its ratio to $\mathrm{PM}_{2.5}$ still below during flaming phase. Higher composition of sulfates, ammonium and potassium were also showed by Rastogi et al, 2014 .

\section{Windrose During Measurements.}

Analysis of the direction as well as the magnitude of wind speed at the site are represented by windrose as depicted at Figure 3. Generally at the two sites, the wind direction comes from North East.:

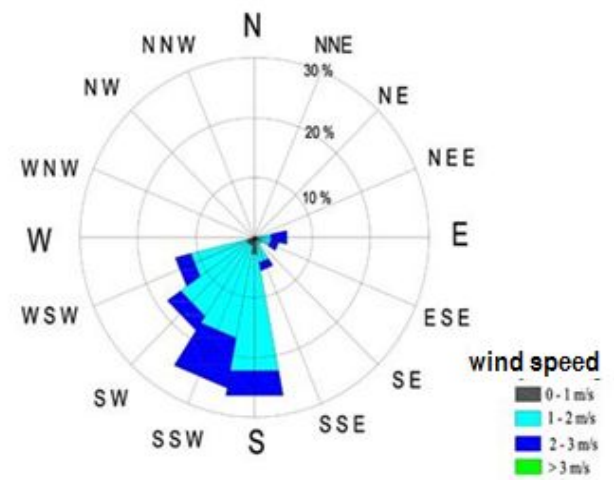

(a) Siak District

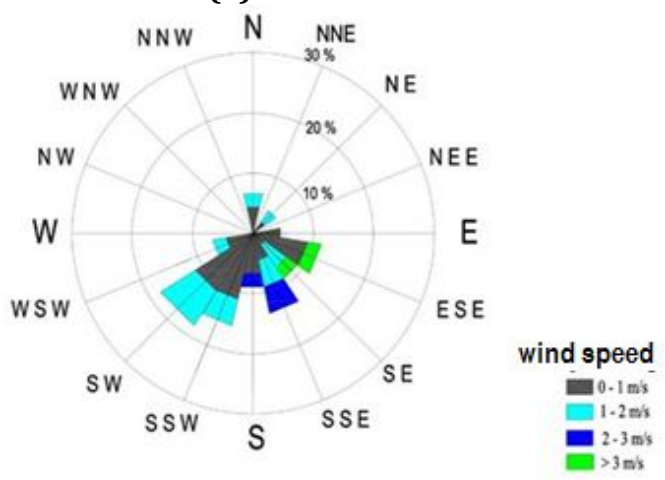

(b) Kampar District

Figure 3. Windrose at Two Sampling Sites

\section{Buffer Zone Design}

The buffer zone area can be determined by using dispersion modeling simulations of pollutant concentrations at a certain distance by taking into account the meteorological factors. This buffer zone should achieve the pollutant concentration at the outside pherimeter of buffer zone in the allowable concentration. For initial analysis we should estimate the pollutant dispersion at the site. The assumptions used in this simulation, namely oil palm plantations on peat land area of 6 hectares $\left(300 \times 200 \mathrm{~m}^{2}\right)$ located at $0^{\circ}$ 53'31,31 "U-102 ${ }^{\circ} 1$ '57,00" T burned on 2 July 2015 and emitted $\mathrm{PM}_{2.5}$ for $24 \mathrm{~h}$. The fires assumed in smoldering phase. The average wind speed during the fire period at the site was $1.6 \mathrm{~m} / \mathrm{s}$. Based on NOAA data, the elevation angle of the sun is $23.05^{\circ}$ giving the day insulation was in slight category. Therefore, the stability class could be defined as B (unstable) and the values of $a, b, c$ and $d$ to the Gauss equation are $0.4936 ; 1.114 ; 0.31$ and 0.897 respectively.

$\mathrm{PM}_{2.5}$ emission factor due to land fire is $15,0 \mathrm{~g} / \mathrm{kg}$ (Akagi et al., 2011) while the other emission factor stated during smoldering fire is $75 \mathrm{~kg} / \mathrm{m}^{2}$ (Rein et al., 2013). Based on the data assumptions and above equations, we can derive the the emissions:

$$
\begin{aligned}
& \mathrm{Ei}=15 \mathrm{~g} / \mathrm{kg} \times 75 \mathrm{~kg} / \mathrm{m}^{2} \times 60,000 \mathrm{~m}^{2} / \text { day } \\
& \mathrm{Ei}=781.25 \mathrm{~g} / \mathrm{s}
\end{aligned}
$$


Difusion coefisien could be determined by:

$$
\begin{gathered}
\sigma=c=0,31 \times 50^{0,897}=10,36 \\
\sigma Z=a \quad=0,4936 \times 50^{1,114}=38,55
\end{gathered}
$$

Based on McAffrey (1995) formula, using estimated surface temperature during fire period then we derived the smoke height $\pm 2,7 \mathrm{~m}$. Then this smoke height can be used for calculating wind speed (Uz)

$$
Z=\quad \overline{0}_{0}=(1,6)\left(\frac{2,7}{10}\right)^{0,07}=1,45 \frac{-}{s}
$$

Then $\mathrm{PM}_{2.5}$ at $50 \mathrm{~m}$ :

$$
\begin{aligned}
& X=Q \cdot K / \pi\left(\sigma_{y} \cdot \sigma_{z} \cdot U_{z}\right) \exp \left(-1 / 2\left(H / \sigma_{z}\right)\right. \\
& =\left(781,25 \mathrm{~g} / \mathrm{s} \mathrm{x} 10^{6}\right) / \\
& 3,14(10,36)(38,55)(1,45) \exp \left(-0,5(2,7 / 38,55)^{2}\right) \\
& =428.609,38 \mathrm{~g} / \mathrm{m}^{3}
\end{aligned}
$$

In this study, the pollutant concentration is estimated at distance of 50,100, 150, 200, 250, 300, 400, 500, 1000, $1500,2000,3000$ and $3500 \mathrm{~m}$. The complete results are shown at the following table:

Table 2. Estimated $\mathbf{P M}_{2.5}$ Concentration at Reference Distance

\begin{tabular}{cccr}
\hline $\begin{array}{c}\mathbf{X} \\
\text { (meter) }\end{array}$ & $\begin{array}{c}\boldsymbol{\sigma y} \\
\text { (meter) }\end{array}$ & $\boldsymbol{\sigma z}$ (meter) & \multicolumn{1}{|c|}{$\mathbf{( \mathbf { u g } / \mathbf { m } ^ { 3 } \text { ) }}$} \\
\hline 50 & 10,36 & 38,55 & 428609,38 \\
\hline 100 & 19,29 & 83,44 & 106543,80 \\
\hline 150 & 27,75 & 131,08 & 47156,75 \\
\hline 200 & 35,92 & 180,60 & 26444,52 \\
\hline 250 & 43,88 & 231,57 & 16883,74 \\
\hline 300 & 51,68 & 283,72 & 11701,59 \\
\hline 400 & 66,90 & 390,90 & 6561,49 \\
\hline 500 & 81,72 & 501,22 & 4189,10 \\
\hline 1000 & 152,18 & 1084,86 & 1039,33 \\
\hline 1500 & 218,94 & 1704,28 & 459,87 \\
\hline 2000 & 283,39 & 2348,13 & 257,86 \\
\hline 3000 & 407,70 & 3688,83 & 114,09 \\
\hline 3500 & 468,16 & 4379,93 & 83,68 \\
\hline
\end{tabular}

Note: $a=0.49 b=1.11 c=0.31 d=0.90$

Ambient $\mathrm{PM}_{2.5}$ concentration could be reduced by absorbing it through buffer zone at ground. One of the vegetation considered best suit for peatfires smoke reduction is Ficus benjamina (Giesen et al., 2003). Other genus of Ficus is Ficus nitida which based on the research has pollutant absortivity rate $0.041 \mathrm{~m} / \mathrm{s}$ at wind speed $3 \mathrm{~m} / \mathrm{s}$ (Freer-Smith et al., 2004). The area of absorption for each tree was estimated $12,05 \mathrm{~m}^{2}$. Thus if we assumed the area land needed for planting a tree is 1 sqm and the effective height of the tree is $13,716 \mathrm{~m}$ (Gilman et al., 1993) then we will get following calculation for deriving total area of required buffer zone. Following are the calculation steps for knowing such parameter:

Flux (Removing $\mathrm{PM}_{2.5}$ )

$\mathrm{F} \quad=\mathrm{Vd} \times \mathrm{C}=\mathrm{F}=0,00041 \mathrm{~m} / \mathrm{s} \times 106.543,7960 \mathrm{~g} / \mathrm{m}^{3}$ $=43,68 \mathrm{~g} / \mathrm{m}^{2}$

Mass removal of $\mathrm{PM}_{2.5}$ is

$=$ F $\times$ absortivity for each tree

$=43,683 \mathrm{~g} / \mathrm{m}^{2} \times\left(12,05 \mathrm{~m}^{2}\right) /$ tree

$=526,38 \mathrm{~g} /$ tree

Final Concentration is derived:

$\mathrm{Ct}=\left(\right.$ Mass removed $\left.\mathrm{PM}_{2.5}\right) /($ Removal volume) $\mathrm{Ct}=(526,38015 \mathrm{~g} /$ tree $) /\left(\left(1 \mathrm{~m}^{2} \times 13,716 \mathrm{~m}\right)\right)$

$\mathrm{Ct}=38,38 \mathrm{~g} / \mathrm{m}^{3}$

Required trees to be planted:

$=\left(106543,8 \mathrm{~g} / \mathrm{m}^{3}\right) /\left(38,377 \mathrm{~g} /\left(\mathrm{m}^{3}\right.\right.$ tree $\left.)\right)=2776$ trees

Required land:

$=$ Number of trees $\times$ Planting area $\times$ wind direction

$=2776=$ tree $\times\left(1 \mathrm{~m}^{2}\right) /$ tree $\times 16$

$=44419,796 \mathrm{~m}^{2}=4,44 \mathrm{Ha}$

Planting area will be surrounded through the fires spot. The design of the buffer zone which is adopted from Syaufina, 2003 is depicted in the following figure.

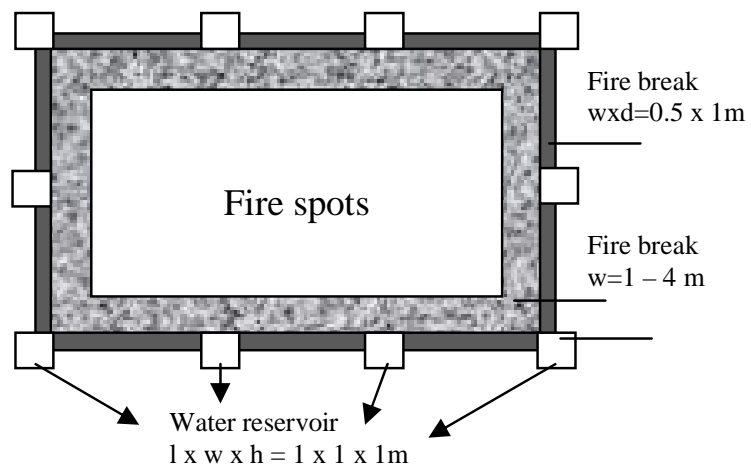

Figure 4. Schematic View of Buffer Zone

Water ditch channel is intended for supplying water continuously to the tree as fire break. This water ditch channel is linked with coastal channel at the sea. Thus it has sustainability of water supply in the fire break even drought condition take place. By applying this method, it is hoped that drainage of peat water table could be prevented along with supplying water for fire-resistant vegetation system in order to prevent uncontrolled burning during peatfires period.

After the trench insulated, to improve the quality of the water in the trench we can plant aquatic plants which are immersed in it. If the water quality is improving, it can be growing media for fish (Syaufina, 2003). This advantage could be expand to other aspects as long as there are supporting political will from the government to assure the sustainability. 


\section{CONCLUSIONS}

The conclusions of this study are:

1. The measured near fire $\mathrm{PM}_{2.5}$ was quite high mounted to more than $800 \mathrm{~g} / \mathrm{m}^{3}$ on average. However the fluctuation of the emission (between samples) was quite high indicating high variability of smoldering phase..

2. Abundant of $\mathrm{Cl}^{-}, \mathrm{SO}_{4}{ }^{2-}, \mathrm{NH}_{4}{ }^{+}, \mathrm{K}^{+}$were detected in $\mathrm{PM}_{2.5}$ composition indicates high contribution of peatland fire on worsening local ambient $\mathrm{PM}_{2.5}$

3. Environmental improvement by proposing buffer zone at fire site might be a viable solutions to prevent fire expansion and provide sustainability of peat ecosystem. However this method should be supported by policies to accommodate other aspect such as economic and local culture.

\section{REFERENCES}

Akagi S.K., Yokelson RJ, Wiedinmyer C,. Alvarado MJ, Reid JS., Karl T, Crounse JD, and Wennberg PO. Emission factors for open and domestic biomass burning for use in atmospheric models Atmos. Chem. Phys., 11, 4039-4072, 2011

Fujii, Y., Iriana, W., Oda, M., Puriwigati, A., Tohno, S., Lestari, P Mizohata, A., and Huboyo, HS 2014.Characteristics of carbonaceous aerosols emitted from Peatland fire in Riau, Sumatra, Indonesia. Atmos. Environ., 87, 164-169, 2014.

Freer-Smith, P.H., El-Khatib, A.A., Taylor, G., 2004. Capture of particulate pollution by trees: a comparison of species typical of semi-arid areas (Ficus nitida and Eucalyptus globulus) with European and North American species. Water, Air, and Soil Pollution 155, 173, 187.

Giesen, W. 1991. Berbak Wildlife Reserve. Jambi. Reconnaisance Survey Report. PHPS/AWB Sumatera Wetland Project Report No 13. Asean Wetland Bureau-Indonesia. Bogor.
Gilman, Edward F., Watson, Dennis G.,1993. Ficus benjamina Weeping Fig. FactSheet ST-251. USA

Hamada Y, Untung Darung, Limin SH, Ryusuke Hatano. 2013.Characteristics of fire-generated gas emission observed during a large peatland fire in 2009 at Kalimantan, Indonesia. Atmospheric Environment 74 (2013) 177-181

Levine, JS 2000.Global biomass burning: A case study of the gaseous and particulate emissions released to the atmosphere during the 1997 fires in Borneo and Sumatra, Indonesia, in Biomass Burning and Its Inter-RelationshipsWith the Climate System, edited by JL Innes, M. Beniston, and MM Verstraete, pp. 15-31, Dordrecht, Norwell

McCafffrey B. 1995. Flame Height. The SFPE Handbook of Fire Protection Engineering, 2nd Ed., National Fire Protection Association, Quincy MA., USA, pp. 2-1 to 2-8

Muraleedharan, TR, Rajojevic, M., Wa gh, A., and Caruana, A. 2000.Chemical characteristics of haze in Brunei Darussalam during the 1998 episode.Atmospheric Environment 34, 27252731.

Rastogi N, Singh A, Singh D, Sarin MM.2014. Chemical characteristics of PM2.5 at a source region of biomass burning emissions: Evidence for secondary aerosol formation. Environmental Pollution 184 (2014) 563-569

Reid, JSR Koppmann, TF Eck, and DP Eleuterio. 2005. A review of biomass burning emissions Part II: Intensive physical properties of biomass burning particles. Atmos. Chem. Phys., 5, 799-825, 2005.

Rein G, 2013. Smouldering fires and natural fuels, C. Belcher (Ed.), Fire Phenomena in the Earth System - An Interdisciplinary Approach to Fire Science, Wiley and Sons, London (2013), pp. 15-34

Syaufina, L. 2003. Guidelines for Implementation of Controlled Burning Practices.Faculty of Forestry. Bogor.

World Health Organization. 2013. Health Effects of Particulate Matter Policy implications for countries in eastern Europe, Caucasus and central Asia.Denmark 